American Journal of Qualitative Research

2022, Vol. 6 No. 1, pp. 139-152

https://doi.org/10.29333/ajqr/11769

(C) 2022 AJQR. http://www.ajqr.org
AMERIGAN

JOURNAL OF QUALTATIVE

RESEARCH

ISSN: 2576-2141

\title{
Identity, Centripetal and Centrifugal Forces, and the Indifference of Love
}

\author{
Douglas L. Kelley ${ }^{1}$ \\ Arizona State University, USA
}

\begin{abstract}
The present autoethnography uses stories, pauses for reflection, and social scientific theory to explore two-plus years of identity deconstruction, as well as passive and active identity reconstruction, following a diagnosis of acute myeloid leukemia and eventual stem cell transplant. I cast these parallel identity processes in terms of centripetal force, a result of loss of volition expressed through victim/patient syndrome, monitoring fatigue, disability bias, isolation, and dehumanization; and, centrifugal force as characterized by an increase in volition and expressed through the contemplative practices of centering prayer, T'ai Chi, and guided imagery. Central to these practices is the dynamism between nonresistance and refocus. I finish this exploration by suggesting that two manifestations of centrifugal force are spaciousness and love arising from indifference.
\end{abstract}

KEYWORDS: Identity, centripetal force; centrifugal force, love, cancer.

Spinning. Slowly at first, so as to hardly notice. Suddenly strong,

a steady force pulling me inward...downward.

TIGHTER-SMALLER. Tighter-Smaller.

tighter-smaller. tighter-smaller.

Poof!

I am gone

These opening lines describe the power of centripetal force as my sense of self was dismantled following a cancer diagnosis and eventual stem cell transplant in 2019. The following account uses aspects of analytic (Anderson, 2006; Bochner \& Ellis, 2016; Tracy, 2013) and evocative (Bochner \& Ellis, 2016) autoethnography (see Kelley, 2020) to investigate the deconstruction and reconstruction of my identity as affected by centripetal and centrifugal force. I finish this narrative romp by somewhat counterintuitively exploring the expression of centrifugal force as spaciousness and the indifference of love.

\section{Initial Identity Deconstruction}

The cancer diagnosis of acute myeloid leukemia (AML) catapulted me into a significant process of identity deconstruction. I had been tired for days as my wife and I launched into a dream

\footnotetext{
${ }^{1}$ Corresponding author; Arizona State University West campus, 4701 W. Thunderbird, Rd., Glendale, AZ 85306.

E-Mail: Douglas.Kelley@asu.edu
} 
vacation - driving to Paso Robles, Northern California and the redwood forests, the Oregon Coast, Gig Harbor, Lake Coeur d'Alene, Jackson Hole, Colorado Springs - but I assumed the fatigue was simply stress that would abate once I relaxed on the open road. However, it was soon clear to me that I wasn't getting better. I began popping ibuprofen and acetaminophen to battle muscle soreness, tiredness, lack of focus. By the time we reached a friend's condo in Depoe Bay, Oregon, I was spiking fevers and battling severe fatigue.

At this time, out of desperation, I ended up at the ER in nearby Lincoln City. Blood tests looked grim, but I didn't know how grim. They wanted to fly me to Portland to be hospitalized. Not a good sign. We pleaded with the ER doc to let us drive home with a few drugs in our pockets - we live only 20 minutes from Mayo Hospital's Phoenix campus. He mercifully consented, provided I make an appointment with my primary care physician while standing there in the ER. Done. Then he looked at my wife, "He can't drive. You can't have an accident because he can't clot. If he starts spontaneously bleeding, go straight to the nearest ER." We left, grateful, but confused. Surely this is a spike in my old autoimmune illness, yes? What does it even mean to bleed spontaneously?

When we arrived at my primary care physician's office, he didn't examine me. In fact, he was almost angry. He had seen the blood test results from the ER in Oregon, "What are you doing here? You should be in the hospital. I've made arrangements for you to be admitted. Your wife can go get your personal items later." An hour hence I was hospitalized for fatigue and fever, as far as I knew. Little did I realize that my new room would be home for the next five weeks.

The first night in hospital it was discovered that I had somehow contracted the e-Coli virus in my bloodstream. "Good news," I thought, "if doesn't kill me." People get sick. That's part of being human. E-coli? Not a problem. I can overcome this. It's who I am. It's what I do.

Two days later the medical team determined how the E-coli had entered my system. I heard the doctor's voice echo against the walls of my recalcitrant ego, "The results from the bone marrow biopsy indicate acute myeloid leukemia (AML)." I was shocked. In disbelief. Wasn't this the same type of cancer my friend Ted had? I have been his friend and helper. He is the cancer patient, not I (see, Beck, 2021, for more on our friendship during this time).

\section{I am active \\ I am healthy \\ I am physically fit \\ I have good social support \\ I provide good social support \\ I have a meaningful spirituality \\ I am FUN for God's sake! \\ I AM NOT the kind of person who gets cancer!! \\ I AM NOT a cancer patient!!!}

I had no time to ease into a new way of understanding myself. Unlike developmental change that is somewhat predictable, I was unexpectedly thrust into a new way of experiencing life and my own identity:

We will start chemo, tomorrow, five days' worth.

You will be in hospital for a month.

\footnotetext{
${ }^{2}$ I do not take lightly the statement, "fun for God's sake." Perhaps in another writing I will explore the meaningful role of play in my life.
} 
You will go home for a couple weeks, then come back for maintenance chemo until your stem cell transplant is ready.

The stem cell transplant involves five more days of chemo to eliminate certain elements of your immune system.

You will spend a month in hospital to allow your white and red blood cells to reboot from the new stem cells.

My head was spinning. My wife and I threw glances to one another. We had not sought this narrative within which we had been abruptly placed. Of which we had little knowledge. Of which we barely believed existed. We had just been drinking wine in Paso Robles with Ann's cousin and her husband. Life was good! Wasn't it?

I ventured, "Don't we want to see how well the chemo works before talking stem cell transplant?" My oncologist drew a large circle on the white board, with a rather tiny circle inside, "That small circle represents the percentage of people who have AML for whom chemo alone works. Based on your genetic markers, you are not in that group."

\section{Remembering as I write: \\ I was diagnosed with AML in July 2019, followed by stem cell transplant in October 2019. Upon my release, end of November 2019, I had to wear a mask to help protect me from potential threats as diverse as desert spores, Valley Fever, influenza, and general infection. One of the main reasons I wore a mask, in those days, was simply to let others know to stay back. People weren't accustomed to masks pre-COVID, so they did tend to give me distance. This necessary insurance contributed to the downward spiral of my social self(for more on the effects of mask wearing, see Kelley, 2020).}

At that moment, I felt my uniqueness as a human being begin to slip away. Overtime I lost my hair, my weight, my clothes (exchanged for hospital gowns), my energy. I became common. Part of the cancer herd. At times, simply a name on a chart. Most poignant was the reduction in volition I experienced during those first weeks. Volition - that which makes us so human. So unique. I was no longer in control over much of my life. My family and I sought to regain control by searching for choices and options other than the path that had been laid for me. Soon we learned that there are few alternative treatments for this aggressive cancer. I asked one oncologist, "What would you do if you were me"? She didn't hesitate, "Your specific situation is a no-brainer. I would do the transplant." I was given some choice as I had to consent to this line of therapy, but it felt much like someone holding a gun to my head and asking for my money - in theory, I had choice, but practically there was little real volition.

An image that represents this loss of uniqueness and volition occurred a few years back. A friend and I were kayaking on the Salt River near Phoenix, Arizona. It was a remarkable fall day. We gazed at the beauty of the cliffs. We stared in awe at the wild horses feeding on the river's rich grasses. We joked and laughed as we heard the roar of the river increase around the bend. Then, rather unexpectedly, we were pulled against our will into a violent rapid for which we were unprepared (this level of torrent was not our map). We made choices as the river carried us beside and against a labyrinth of partially submerged rocks, but we were little match for the strength of the current. I was eventually swept near the eastern bank and into a large, low hanging mesquite tree, to which I clung as the river pulled my paddles, iPhone, and flotation device down the river.

So, too, my initial cancer experience - a forceful current moving me at will...against my will...down a river of great uncertainty and danger. I had choices along the way, but the initial 
force of the current was overwhelming, and there were rapids that were simply not on my map. I grasped desperately at what I could in order to stabilize me, but the river defined the moment, stripping much of what I knew as self.

\section{Centripetal Force and Identity Deconstruction}

I didn't initially recognize that this time of identity deconstruction was influenced by centripetal force. As the opening lines to this essay reveal, I sensed my social/relational selfbecoming smaller. Pulling inward. Downward. Aspects of $m e$, aspects that I valued and that served as identity anchors, were diminishing as I spiraled helplessly in a whirlpool of darkness and isolation - my social self-becoming smaller and smaller as time progressed.

Five processes contributed to this centripetal identity spiral: victim/patient syndrome, monitoring fatigue, disability bias, isolation, and dehumanization (Kelley, 2020). Victim/patient syndrome for me was facilitated in four ways. First, my sense of self began to shift as doctors and nurses took control of my immediate experience - "Please wear this gown; opening to the back," "You have an x-ray at 6:10 a.m.," "Checking vitals is at 4 a.m. and 4 p.m." To be clear, my experience at Mayo Hospital Phoenix campus was exceptional. Yet, because I trusted them, I also turned over much of my volition, my "self," to them. Second, my sense of being victim/patient was facilitated by my all-too-real physical limitations. Initially, I could barely walk around the nurses' station ten times. Later, at home, I watched my wife take care of "my" home duties, such as caring for the pool (I had a triple lumen catheter protruding from my chest that couldn't get wet) and picking up dog waste (no foreign bacteria, please). Third, my initial mask wearing (pre-COVID) was a constant reminder that something was "wrong" with me. When wearing the mask, I was clearly different from everyone else, but not different in the life-giving ways I wanted (see Kelley, 2020). Fourth, these first three elements contributed to victim/patient syndrome through creating a sense of childlikeness - not in the beautiful sense of innocence, openness, and play, but instead through the experience of being less competent (frequently knocking things over; having my wife cut my food for me), losing many of my adult roles (waiting outside a store while my wife finished a cash transaction), and feeling reduced energy (fatigue requiring multiple naps and early bedtimes).

Remembering as I write: The childlike qualities that I experienced as part of victim/patient syndrome, was most evident when at one point my GVHD (graft vs. host disease - the grafted cell's response to the host cells and organs) reactivated in the form of a severe rash that covered over 80 percent of my body. My hand was so tender that I could not bear the pressure of a fork against my palm as I endeavored to cut through simple food items. As such, my wife prepared my food in bite-sized morsels, much like my mom had so many years previous.

Part of my willingness to turn over key life decisions to the Mayo staff was rooted in what I have called monitoring fatigue - a fatigue of constantly monitoring oneself and one's environment and making choices related to those elements. I was monitoring my body, monitoring my energy, monitoring my blood counts through the Mayo portal each morning, monitoring visitors who always posed a threat of carrying some unwanted virus into my secure hospital room. Days when I was home, I added to this list the monitoring of self and others as I walked our neighborhood. What is the wind direction in relation to where conversational partners are standing? How do I maintain my distance from this "close talker?" How do I respond to "huggers"? The constancy of 
monitoring became exhausting over time. Plus, there was the emotional strain of wondering, "Am I being too careful?" It soon became easier to pass a neighbor with a nod and wave than to try talking with a mask on, six-feet apart, and maneuvering so that I wasn't downwind from a heavy breather. To add insult to injury, rather than my normal short-sleeved shirt, shorts, backward ball cap, and flip flops, I was now wearing a long-sleeved shirt, long pants, broad-brimmed hat, neck gaiter, gloves, and...closed toed shoes. Each of these items felt like barriers between me and the world I had known.

Disability bias continued my downward identity spiral. This occurred in two ways. The first way was seeing my new self reflected in the eyes and reactions of others (e.g., uncomfortable at the distance we were maintaining; aware of my medication-induced puffiness; choosing to take the easy road and talk to my wife, Ann, rather than me). I began to slowly internalize these perceptions. Significantly, I now saw myself as no longer an appealing communication partner. The second way was more my own undoing. Keenly aware of new limitations (e.g., I could experience dizziness when standing, I bruised and bled readily), I began to limit my activity and let others (my wife, in particular) do for me. Driving, taking out the garbage, changing light bulbs were now buried parts of my former self.

\begin{abstract}
Reflecting as I write:
As I am writing, a text-string is going on between friends. My wife, Ann, and I sing with a local semi-professional chorale. (I'm not currently singing because I am still immune suppressed.) Last night was rehearsal and Ann and our friends/singers went out afterward. The fun has continued with this morning's text-string. I'm included (thankful to them for that), but I feel like to respond would be to intrude on a private space of which I am no longer really a part. Self-imposed isolation. The whirlpool pulling me farther inward, downward, if I am not watchful, careful.
\end{abstract}

At this point, the centripetal force led me to a sense of self-imposed isolation. It was easier to be home alone, or just with my wife, than in a public setting. There was less to monitor, less to explain, less energy to expend. Significantly, this self-imposed isolation became self-reinforcing. I began to find that I didn't miss the interaction with others. Is this a new me that I'm experiencing, that I should accept and embrace, or has my true sense of self gotten buried deep within the waters of a deconstructive whirlpool?

\begin{abstract}
Reflecting as I Write:
I'm wondering how we know who we are, really? I've written elsewhere about notions of the true self (Kelley, 2021), but how does one know when one finds this "true" inner core? I remember a decade ago, when writing my first sole-authored book, I was so content to write and not see other people that I actually asked my wife if she thought I was okay. My social self is generally so charged by being with others that I perceived this new twist on my experience as...something must be terribly wrong.
\end{abstract}

Ultimately, these preceding factors culminated in feelings of being less human. Central to our humanity is the ability to adapt and change (Oelofsen, 2009). And, although I was changing, most of it was not intentional, at this point, but rather a passive identity shift facilitated by centripetal force pulling me downward away from my former self, inward away from my former connectedness. This sense of dehumanization was reenforced as my body - $80 \%$ covered in rash at 
times, and often with tubes protruding from my chest, side, or neck - seemed more and more like that of an android out of the most recent Star Trek series.

\section{Passive Identity Reconstruction}

I initially conceptualized centripetal force as deconstructing my identity. However, upon reflection, I have come to realize that not only was I engaged in the experience of mourning the lost elements of my former self, but I was also grappling with a new sense of self that was emerging. This latter process of passive identity reconstruction felt as if a new self was coming into being, bereft of my own volition. In this way, parallel patterns of identity work were taking hold deconstruction was not resulting in elimination of identity but, rather, in reconstruction of a newly materialized self.

Passive identity reconstruction began almost as immediately as deconstruction had commenced. While clinging to my crumbling identity as if it were that low hanging mesquite branch, rushing water ready to sweep me away if my grip only weakened, I experienced a tension between going with the current (accepting that I had joined the world of cancer patients and survivors) and finding a shallow that would allow me to trudge across the river's flow and take a less traveled path. Perhaps many simply accept the traditional course, but I've never been one to want to walk exactly where someone else has. This may sound bold and adventurous, but it is not always from good intentions. I instinctively resisted that which I felt was being forced upon me - I was now a cancer patient, but I couldn't say the word, cancer; I wanted to live, but I didn't want to be a cancer survivor; I was willing to undergo hardship, but I wanted linear progress, everything tied up neatly in a bow.

Although there were certainly positive aspects of wanting to venture off the common path, in reality, some of my response to the passive identity reconstruction was simply a denial of what was happening to me. If I didn't say cancer, then maybe I wouldn't have cancer. Not only did I not want to take the common path, I didn't even want to admit that I was on the mountain. In this regard, I resonate with Muriel Strode's (1903) oft-quoted statement, "I will not follow where the path may lead, but I will go where there is no path, and I will leave a trail." That's a move in the right direction for me, at least I'm back on the mountain. And, yet, I have also come to realize that as I set off on my own, the terrain keeps pushing me toward an existing path because, indeed, it is in many ways a good place for a path. My wife and I have experienced this numerous times as we've followed well-worn deer, elk, and horse trails traversing the forests near our mountain cabin. It seems there can be a healthy tension between following the existing path when prudent, while at the same time being willing to forge one's own path when necessary. I can't help but be drawn to Robert Frost (2002) as he beckons us to take the road less travelled.

Early on, however, in spite of my best efforts to forge my own way, I continually found myself on the traditional path (passive identity reconstruction). I was now a person who had an oncologist - my oncologist! I had regular appointments with Mayo staff. I even got to the point where I actually missed going in for tests and checkups when they moved me from a three-a -week to a once-a-month to an every eight-to-twelve-week schedule. Also, I found that many of my previous identity anchors - characteristics that in the past facilitated hiking off suggested paths had been dis-abled. In particular, I could no longer use my active lifestyle, my just-enough-ADD personality, and my love of the outdoors to cope with my stressors. Instead, because of my compromised immune system, I was now limited in terms of where I could go (I was provided a hospital room with special ventilation to prevent air from other rooms being cycled into mine) and who I could see. There was little room for spontaneity. So, I clung to what was left of who I was and watched the river flow beckon me on. 
Remembering as I write: Although I did very little professional work during my first five weeks of hospitalization, I was able to hold on to parts of "Doctor Kelley," the professional me, through a couple of serendipitous happenings. As a communication scholar I thrill to offering others new perspectives, new ways of seeing their relational worlds. Or, if you will, I love to be a catalyst for new relational frames (Kelley, 2017). In this regard, I have often used story as a means of helping others re-see their own relational experience. Well, it turned out that some hardened lymph nodes in my neck generated quite the interest from those teaching medical students on the Mayo campus, so I was asked if instructors could bring small groups of five to eight students into my room and have me tell them my lymph node story. Are you kidding?! This is what I do. A big, Yes!, to being Doctor Kelley, again. As I shared my story with various groups over the following week or two, I felt myself settling back in the groove. The good doctor was definitely in.

An experience with one particular group stands out as I attempted to cling to my former identity. I was standing and speaking to a group of six students and instructor when I noticed a woman who looked disinterested, also standing, in the front of the group. As a seasoned teacher, I was used to this - the student who for some reason sits in the front row and looks bored out their mind. I continued to watch this student as I told my saga, hoping to perhaps win her over, when I began to notice her swaying. Suddenly, she pitched forward. I lunged downward toward her collapsing body and placed my hand under her head as she hit hard - my palm protecting her skull from the full impact of the flooring. Others in her group rushed to her aide, roused her from the faint, and quickly moved her to the emergency room for examination. It turns out that she hadn't eaten all morning due to a migraine headache. She was going to be just fine. But, through all that had transpired I had suddenly become the hero.

People began randomly stopping by my room, "You are the guy that saved the student, aren't you? Awesome." Perhaps my favorite recognition was when my oncology team came by the next morning. News had traveled fast and they were a bit stunned and bemused, "So you caught that student before she hit the floor? And you're the patient!" Bam! Another little bit of me, my uniqueness, to hold on to. A move away from the common for a short period of time. But clinging to flashes of my former self was not sustainable. I needed a more stable sense of self.

\section{Active Identity Reconstruction}

In tension with the centripetal forces that were at work deconstructing my former identity and leaving a skeletal sense of self in its place, centrifugal force exerted itself through active identity reconstruction during the darkest days. ${ }^{3}$ The seeds for this active reconstruction had been

\footnotetext{
${ }^{3}$ It would be easy to construe centripetal force as negative and centrifugal force as positive, given my description. It is to be noted that centripetal and centrifugal forces are without value. In contrast to how I have experienced these,
} 
planted long before. Thankfully, twelve years prior, I had embraced a contemplative form of my own spirituality. And while, at the time of my diagnosis, I still considered myself a spiritual toddler in this arena, I was familiar with the practices of silence, solitude, and mindfulness, as expressed through centering prayer, T'ai Chi practice, and guided imagery. My hospital stays, and even my short returns home, became fodder for development of my slowly emerging contemplative self.

Hospital stays were often characterized by long periods of being alone. Of course, there were many who visited, the nurses were never absent long without checking vitals, the docs made their daily rounds, and there was one amazingly positive man who frequently brought my meals, but afternoons and evenings could be lonely times as everyone, tired from their own days of activity (which might have included visiting or caring for me), headed home to other responsibilities or for their own restoration. Thankfully, years of contemplative practice enabled me to embrace this solitude. In particular, centering prayer created a foundation for how I practiced T'ai Chi and used guided imagery to aid my recovery.

Fifteen years, previous, I began the practice of centering prayer (20 minutes in the morning daily). I deeply resonated with this meditation-like practice of silence and awareness of the divine (Beourgault, 2016; Keating, 2006) as I was drawn to the peace of slowing my ADD mind and the sense of calm it produced in my body. My overall experience was one of safety and contentment. Central to the practice for me was: nonresistance and refocus - a rather beautiful dialectic between passivity (as experienced intentionally through nonreactivity and receptivity) and action (an intentional refocusing of my mind; a returning to my place of safety) that resulted in a profound sense of presence. As I would sit quietly, stray thoughts entering my mind uninvited, I would allow them to pass through uninterrupted, only to refocus, bringing my mind home. Remarkably, there is great life and presence in this gentle movement from distraction to refocus (Beourgault, 2016). There was no fighting or resistance of these wannabe guests that had crashed my mental solitude. I would simply let them pass, then return to my focus. No failure. Only presence.

This became the central process that characterized my recovery - let the medical interruptions pass by, uninterrupted, then refocus on being present in the moment. There is nothing "bad" about the medical moments, it's just that they are just that - moments. Moments to be lived, along with the multitudinous other moments that occurred subsequently. It may sound trite in light of the current surge of mindfulness talk, but I began to live what I had known all along - all I have is...now - playing cards with my wife, watching a football game with my brother-in-law, conversing with my sons, chatting with a technician before sliding into the hammer-filled tunnel designed to provide an MRI, encouraging a nurse after he brings me melatonin at $11 \mathrm{pm}$ and ends up revealing his deep relational pain. Regardless of the context (this morning's fatigue, this afternoon's decision to put me on diuretics), I still had now.

The process of nonresistance and refocus became rich contemplative practice as I chose a path of contentment and solitude over loneliness. Centering prayer, which had often been a struggle when I was physically healthy, made itself available to me in a new way as my outward and inward distractions diminished and my cognitive and physical energy became more focused on the simple things which were lifegiving...now.

One way I experienced the now was movement. I complemented the stillness of centering prayer with the equally prayerful practice of T'ai Chi movement. Thankfully, a few years previous, a health practitioner introduced me to T'ai Chi. I was eager to study this practice because I had long been interested in mind-body connection. In particular, I had been fascinated by the prayer of Orthodox Jews which involves the whole body (shuckling). It wasn't long before my T'ai Chi

centripetal force could be a stabilizing force for identity, and centrifugal force could be one of dispersion rather than finding a secure, spacious sense of self. 
practice became one of movement as prayer. Consistent with my Christian foundation, chi, the life force, became associated for me with Christ, also the life force. So, most evenings, while hospitalized after the stem cell transplant, I engaged 10-20 minutes of T'ai Chi movements as prayer, focusing on a holistic sense of balance, strength, and a unification of my body, mind, and spirit. When thoughts intruded into my T'ai Chi practice, I chose not to resist them, but rather gently let them pass as I refocused on my movement, on my presence.

\begin{abstract}
Remembering as I write:
Rather humorously, I was lightly reprimanded by one of my favorite doctors, who came into my room one morning as I was sitting on a yoga mat engaged in some T'ai Chi stretches, "You're an adult and can make your own choices, but I know where my shoes have been in this hospital and certainly wouldn't be sitting or lying on the floor, especially without much of an immune system." We smiled, and I took her advice regarding the floor, but continued to focus on T'ai Chi exercise that I could practice while standing.
\end{abstract}

A third element that contributed to my active identity reconstruction was guided imagery. Years before I was given guided imagery audio recordings by my brother- and siter-in-law. These recordings tapped my imagination in order for my mind and body to engage the healing they knew how to do. Over time the facilitator's voice became soothing and relaxing to me and, significantly, I learned to trust my own inner voice for healing. And, once again I relied on my foundation of centering prayer to let intruding thoughts pass unobstructed while returning my focus to suggested images. These three practices of centering prayer, T'ai Chi, and guided imagery contributed to a great sense of peace during my treatment and rooted my naturally positive outlook into a more sustainable foundation while I was, yet, surrounded by uncertain health outcomes.

Reflecting as I write:

I have been fighting all week to get to this writing. Although not on the university campus, my workload has increased this semester, along with certain community commitments. When released from hospital, November 2019, five weeks after my stem cell transplant, I was afraid of losing the sense of peace and tranquility that I had gained, in part, from embracing a more contemplative identity and letting go of the high-paced, high-energy self that had served me well, in so many ways. I began to pursue action and a mindset that embraces, as a favorite coffee mug of mine puts it - slow down, life is good.

Interestingly, a few months after my hospital release, Dan, my youngest son, twice told me that he noticed a difference in me - I was calmer, more anchored. I thought, "I feel it; but, is it that obvious? How do I not lose this sense of being?"

Two additional aspects of active identity reconstruction or, at times, active resistance to passive identity reconstruction, are worthy of note. First, I took specific action not to be defined by my cancer or my stem cell transplant or my recovery. This active resistance has manifested in various forms. Just the other day I told Ann that, when with other people, I want to be certain not to talk only about my health. It is the easy go-to topic because people often initiate: "How are you 
feeling?" or "How are the treatments going?" or "You look good!" These questions are seductive as they put the focus on me and, yet, if not responded to well they create a unidimensional persona (as we often joke in our family, I become cancer boy or stem cell guy).

Second, I've rather intentionally avoided reconstructing my identity around "cancer survivor" groups. I'm not saying this with any valuation of these groups or my own behavior. The fact is, I simply don't think of myself as having survived cancer. Not because I think the AML is likely to return, but because I do not associate my sense of self with cancer. Although there may be some virtue and resiliency in this approach to my cancer experience, it also is most certainly a manifestation of my tendency to emotionally forget "negative" events in my life.

\title{
Remembering as I write: \\ In contrast to labeling avoidance, related to my cancer, my active identity reconstruction has also included some humorous moments of strategic labeling between me and my family. Frequently, when Ann or one of our boys asks me to do something that I don't want to do, I respond, "Did I mention that I had a stem cell transplant"? They've learned to roll their eyes, chuckle, and tell me to get in there and do the dishes or finish laying brick in the backyard. As is common to intimate relationships, with Ann, I often truncate this process by simply giving a little... cough! In response, she playfully swats me on the rear end to get me moving.
}

To fully understand my active identity reconstruction, it is essential to recognize my tendency toward emotion-based forgetting. I am able to cognitively remember my leukemia diagnosis and month-long hospital stays, but my emotional connection to those events has mostly atrophied. To me, they seem like ancient history. As such, rather than call myself, cancer survivor, I am more likely not to label my last two year's journey at all, preferring instead to use a journey metaphor, "Yes, cancer and stem cell transplant are part of my journey. I learned a lot from them. But, I must choose how to live today. How about you?" Of course, in statements like these I am minimalizing aspects of my experience and diverting the conversation.

\begin{abstract}
As I Write: Reflection
Today I posted on the social media platform, Caring Bridge, to update those faithful followers of my journey as to my relatively stable health at present - two years and one day post-transplant! In response, I received a text from Vince, my friend and colleague, stating, "Nice to see your post on Caring Bridge. What a ride it has been. Heart emoji." My initial internal response took the form, "Was it? Gee, I guess it has been quite a ride." This somewhat emotionally vacant response tendency makes me extremely resilient, but has its own many downsides, at times, one of which is limiting my ability to be emotionally available.
\end{abstract}

As you've read the last section you may have noted centripetal and centrifugal forces in tension in my recovering life. I have begun to appreciate that much of our "healthy place" is learning to live in such tension. As my experience of centering prayer has taught me, it is the dynamism of the tension wherein we find presence. A recent medication change has produced renewed energy that has, interestingly enough, resulted in an increased ability to look outward, along with the parallel energy to look inward. I am no longer swept into the swirling whirlpool that once compressed my identity or flung it outward into the physical and relational world. Currently, 
neither centripetal or centrifugal force has enough power to dominate my identity reconstruction. Rather, my renewed physical and cognitive energy has created a relatively solid structure from which to keep these two identity and relation-based processes within a manageable tension.

As I Write: Reflection

I have been off prednisone, as of today, three weeks, after a two-year regimen that was necessary to prevent the emergence of a rash caused by GVHD. The increased energy I wrote of, above, is a result of this change, although prednisone is notorious for giving you energy. Too much energy, at times. The interesting thing is that I was largely unaware before weaning myself off this steroid of the full effect it was having on how I felt. There is so much good research being conducted to understand how chemicals affect our brains but, truth be told, I want to be able to simply will myself to feel as I want to feel, to think as I want to think, to act as I want to act. This is one of the powerful elements regarding centering prayer/meditation for me, it is a way of restructuring my thinking, feeling, and actions without drugs or other external stimuli.

\section{Contemplation, Spaciousness, and the Indifference of Love}

$$
\text { Here I sit... }
$$

Alone, but not lonely

Naked, but not cold

Without thought, but not thoughtless

Vulnerable, but safe

The beauty of the mountains caresses me

The feeling of the sun's rays warms my soul

Contentment eases my pain

As inner peace heals my brokenness

I am living...

Large enough to accept what is

Grand enough to generously give

Open enough to embrace those who come near

Safe enough to sit quietly with who I am

Distance allows me to see

Trust allows me to listen

Curiosity allows my release

Indifference allows me love

I am unique, I am common

I am distinctive, I am same

I am eternal, I am the blink of an eye

I am spacious 
Active identity reconstruction has been most characterized by giving the contemplative self a more central position in my array of identities (husband, father, grandfather, professor, teacher, writer, singer, volunteer, spiritual director). Interestingly, although contemplation might seem at first to be primarily an expression of centripetal force drawing one to isolate in silence and solitude pondering one's own thoughts and navel, in my experience contemplation is most characterized by centrifugal force - an outward thrust that has become for me closely associated with the ideas of spaciousness and the indifference of love.

During my stem cell stay at Mayo hospital I had a room with a view of the McDowell Mountains, a range that is located northeast of the Phoenix metropolitan area. My first action after "checking in" to this room was to move a table near the window so that I could sit and gaze at the desert peaks. Interestingly, one nurse told me that she had never seen anyone do this. I spent mornings, when not busy with medical tests and examinations, drinking green tea (I had sadly lost the taste for coffee), snacking on breakfast foods, and reading Belden Lane's (1998), The Solace of Fierce Landscapes: Exploring Desert and Mountain Spirituality. Lane spoke to my new sense of mortality, which at times engendered feelings of lostness and vulnerability coupled with a sense of vast emptiness. I pondered Lane's account of peering into a deep canyon, while holding only to a blue juniper, "Sensing an invitation to emptiness, I'm drawn there by an indifference whose other name is love...I become part of a great remembered wholeness that's strangely akin to love" ( $p$. 59). I didn't understand his statement, completely, but it had the ring of truth. The vast loneliness and apparent barrenness that can characterize the desert experience, can also be the germination of knowing you are part of a whole, of existing in love.

Six weeks before my diagnosis, Ann and I had undertaken a rigorous Colorado River rafting adventure through the Grand Canyon. Two-hundred-and-twenty-six miles in eight days. For my reading during our down times, I had taken Fierce Landscapes. Providentially, Lane's notion of indifference provided me a lens with which to experience the sheer magnitude of the Canyon. Its spaciousness. The tumultuous rapids and towering canyon walls. Even its profound sense of solitude.

Ironically, some of my spacious, indifferent, solitudinous experiences in the Canyon were most salient when on the groover. (Ironic, because I'm known in our family for espousing a norush policy for time sitting on the porcelain throne.) A groover is essentially an outdoor toilet consisting of a seat attached to a metal box with handles, and a secure lid designed to contain human waste during the trip. It's called a groover because in days gone by these makeshift toilets were built from ammo containers that left grooves on your derrière. The groover was always placed in a location away from the main camp, but with a view. So, while "doing my business" I was in my groove, so to speak, dwarfed by the immensity of the Canyon. As I sat, I would contemplate that if tossed from our raft I would likely bob and sputter until I disappeared into the muddy brown, 48-degree water of the Colorado. The massive rock formations wouldn't blink. The crashing waves would not pause for a second. And, yet, within the midst of this seeming indifference, I felt safe, content, beloved. As Lane (1998) artfully describes, "God hides from us in an act of loving play, wooing us to the very abandonment that makes love possible" (p. 74).

In this way, each morning when I rose from the groover to re-join the others, I would leave, not only with grooves on my rear end, but also with grooves on my soul. I would walk away content, knowing that I was safe and secure. Insignificant in the grand scheme of things. A speck in the visual field of a divine spy glass. Yet, loved.

The Canyon experience prepared me for another groover of my soul - leukemia. As the Canyon groover wore deep ruts into my shadow side, I realized that if I was mindful enough to look up from the trampled ground beneath my feet, even the towering canyon walls could not dwarf the love I sensed there. So too, my identity trek through a wilderness strewn with medical 
challenges, coronavirus quarantine, and various forms of indifference embedded in the sheer enormity of the medical system, culminated with the discovery of love hiding in the spaciousness of it all.

So, sitting in room 4 East - 53, I pondered my spacious life, unconfined by this 200-squarefoot box. My sterile hospital bed and various medical devices physically dominated the space. Yet, the mountains outside of my window were ever present. They beckoned memories of lostness and abandonment in the Canyon. Memories with emotions intact. No emotional forgetting here. I felt, again, the peace of knowing that whatever the outcome of my journey, I was in my place. A part of the universe as intended. In the midst of wholeness. Spaciously loved. As author and poet Rainer Maria Rilke (2021) offers, "Everything will become easier once you hold to nature, to the simple and insignificant, truly seen by so few" (p. 34).

This counterintuitive experience, feeling a sense of belonging and love in the midst of extraordinary indifference, is in part due to the nature of spaciousness as one manifestation of centrifugal force (Kelley, 2020). For me, the idea of spaciousness is represented by an image of a mountain meadow with trees and peaks towering in the distance. I stand at the meadow's outer edge, arms held wide, peering over tall grass waving in the field. I feel small and fragile in sharp contrast to the rugged mountainscape. Yet, I feel safe...content...loved. The sun's warmth penetrates my shirt. The breeze's coolness caresses my skin. I am dwarfed by the visual beauty. I am overwhelmed and taken captive by my own sensory response. A friend of Teddy Roosevelt's recounted that as they sat together one-night star gazing, contemplating the sheer magnitude of the universe, Roosevelt offered, "Now I think we are small enough! Let's go to bed."

Small. Insignificant. Humble. Safe. Content. Loved. This experience of openness, magnanimity, and grandeur translates into a centrifugal freedom to be and to reconstruct oneself in relation to others - gracious, thankful, generous, loving - outward looking, yet cultivating a deep sense of the inner self.

\section{Acknowledgement}

I am grateful to Annegret Hannawa and Debra Sequeira for their comments on an early version of this manuscript.

\section{Conflict of Interest}

I have no conflicts of interest to disclose.

\section{References}

Anderson, L. (2006). Analytic autoethnography. Journal of Contemporary Ethnography, 35, 373395. https://doi.org/10.1177/0891241605280449.

Beck, J. (2021). The awful coincidence of 2 friends who got the same cancer. The Atlantic. https://www.theatlantic.com/family/archive/2021/07/how-support-sick-friend/619541/

Beourgault, C. (2016). The heart of centering prayer: Nondual Christianity in theory and practice. Shambhala.

Bochner, A., \& Ellis, C. (2016). Evocative autoethnography: Writing lives and telling stories. Routledge.

Frost, R. (2002). The road not taken. In L. Untermeyer (Ed.), Robert Frost's poems (p. 219). St. Martin's Press.

Keating, T. (2006). Open mind, open heart. Bloomsbury Academic and Professional. 
Kelley, D. L. (2017). Just relationships: Living out social justice as mentor, family, friend, and lover. Routledge.

Kelley, D. L. (2020). The person within the mask: Mask-wearing, identity, and communication. American Journal of Qualitative Research, 4, 111-130. https://doi.org//10.29333/ajqr/8712

Kelley, D. L. (2021). Intimate spaces: A conversation about discovery and connection. Cognella.

Lane, B. (1998). The solace of fierce landscapes: Exploring desert and mountain spirituality. Oxford University Press.

Oelofsen, R. (2009). De- and rehumanization in the wake of atrocities. South African Journal of Philosophy, 28(2), 178-188.

Rilke, R. M. (2021). Letters to a young poet: A new translation and commentary (A. Barrows \& J. Macy, Trans.). Shambhala.

Strode, M. (1903) "Wind- Wafted Flowers." The Open Court, 1903(8), Article 5. https://opensiuc.lib.siu.edu/ocj/vol1903/iss8/5

Tracy, S. J. (2013). Qualitative research methods: Collecting evidence, crafting analysis, communicating impact. John Wiley \& Sons.

\section{Notes on Contributor}

Douglas Kelley (Ph.D. University of Arizona) is Professor of Communication and Lincoln Professor of Relationship Ethics at Arizona State University. His research and teaching focus on how relational partners can treat one another humanely through their responses to hurt and struggle, and experience of intimacy and love. Professor Kelley is recipient of NCA's 2017 Bernard Brommel Award for Family Communication and has authored seven books, including Just Relationships: Living Out Social Justice as Mentor, Family, Friend, and Lover and Intimate Spaces: A Conversation about Discovery and Connection. He actively teaches and pursues reconciliation in his local community.

Manuscript received January 10, 2022

Final revision received February 11, 2022

Accepted February 14, 2022 